TARNOWSKIE STUDIA TEOLOGICZNE 35 (2016) NR 2, S. 179-182

http://dx.doi.org/10.15633/tst.2115

Mateusz Switek

UNIWERSYTET PAPIESKI JANA PAWŁA II W KRAKOWIE

\title{
Ekonomia inspirowana miłością (Tarnów, 7 kwietnia 2016 roku)
}

Tak jak co roku na wiosnę, 7 kwietnia 2016 odbyła się w sali konferencyjnej Małopolskiego Urzędu Wojewódzkiego w Tarnowie sesja naukowa organizowana przez biskupa tarnowskiego oraz starostę tarnowskiego. Współorganizatorem był Wydział Teologiczny Sekcja w Tarnowie Uniwersytetu Papieskiego Jana Pawła II w Krakowie, zaś prowadził ją ks. dr hab. Marek Kluz. Tegoroczne spotkanie pt. Ekonomia inspirowana miłościa dotyczyło natchnień płynących z etyki chrześcijańskiej dla życia gospodarczego i moralnych wyzwań stojących przed jego uczestnikami.

Sesję zainaugurował bp dr Andrzej Jeż, który zwrócił uwagę na nadal widoczne w życiu społecznym skutki komunizmu jako okresu niszczenia moralności publicznej. Zaapelował o dostrzeżenie konsekwencji grzechu także w ekonomii oraz szukanie rozwiązań przez zmianę priorytetów. Etyka, zwłaszcza dbałość o pracownika, powinna stać przed zyskiem. W części wstępnej sesji głos zabrał także wicestarosta tarnowski Zbigniew Karciński, przypominając o wartości personalizmu ekonomicznego Jana Pawła II. W podobnym duchu wicewojewoda małopolski Józef Gawron eksponował znaczenie Dekalogu i Przykazania miłości dla życia gospodarczego.

Pierwszy referat Między Bogiem a mamona przygotował ks. dr hab. Piotr Łabuda z UPJPII (Wydział Teologiczny Sekcja w Tarnowie). Wykład stanowił przegląd wypowiedzi i czynów Chrystusa oraz apostołów, które dotyczyły tematyki bogactwa. Celem było opisanie stosunku Jezusa do całej rzeczywistości ekonomicznej. Wbrew oczekiwaniom poza „biada wam bogacze” z Łk 6, 24 trudno znaleźć jednoznaczne potępienie zamożności przez Chrystusa. Ostrzegał on raczej przed pokusami, ryzykiem zniewolenia przez majątek, pokładania całej nadziei w rzeczach. Prelegent zwrócił uwagę na korzystanie przez Jezusa z hojności zamożnych przyjaciół, wizyty u bogaczy oraz konstruowanie pouczeń na motywach czerpanych ze świata ekonomii, 
czego przykładem jest choćby przypowieść o talentach. Jezus unikał przy tym wypowiedzi o charakterze rewolucyjnym, choćby w temacie obowiązywalności podatków. Także w Dziejach Apostolskich nie jest zdaniem ks. Łabudy bezwzględnie postulowana rezygnacja $\mathrm{z}$ dóbr czy wspólnota majątkowa, praktykowane w kontekście oczekiwania rychłej paruzji. Chodzi o dyspozycyjność wobec potrzeb Kościoła i wrażliwość na ubogich. Przeprowadzone analizy skłoniły autora do wniosku, że w Nowym Testamencie pieniądz nie jest sam w sobie wartościowany moralnie, jest tylko środkiem, narzędziem. Jako owoc pracy i panowania nad ziemią może być używany zarówno w imię egoizmu, jak miłości.

Kolejny wykład przygotował dr hab. Wiesław Gomuła, prof. uJ, dyrektor Oddziału Okręgowego NBP w Krakowie. Wystąpienie Trudności $w$ etycznym korzystaniu z pieniądza łączyło w sobie optykę ekonomiczną z socjologiczną. Prelegent podkreślił, że pieniądz jako twór konwencji społecznej stanowi nośnik informacji oraz władzy i gwarantuje stabilność. Korzystanie $z$ tego narzędzia obciążone jest zagrożeniami etycznymi, które po kolei sygnalizował w swej wypowiedzi. Tak na przykład rozchwiana inflacja, psucie lub fałszowanie pieniądza uderzają w bezpieczeństwo jego użytkowników. Wirtualizacja zobowiązań czyni je abstrakcyjnymi i zmniejsza opory choćby przed zwłoką w spłacie. Podobnie bywa w obrocie bezgotówkowym - „brak twarzy Drugiego” osłabia moralne zobowiązanie, ułatwia ucieczkę od uczciwości. Prof. Gomuła zwrócił także uwagę na skomplikowany charakter „daru”, np. łatwego kredytu, który może jeszcze pogorszyć sytuację biorcy, zamiast mu pomóc. Te rozważania skłoniły mówcę do podkreślenia zasadniczego znaczenia relacji osobowych, więzi społecznych dla prawidłowego przebiegu procesów ekonomicznych. Bez nich gotówka łatwo staje się obiektem kultu, a pieniądz wirtualny narzędziem spekulacji, karmiąc rozrost instytucji finansowych i kolejnych baniek inwestycyjnych.

W referacie Ekonomia pilnie szuka etyki dr Artur Pollok z krakowskiego Uniwersytetu Ekonomicznego zaprezentował cenną podstawę dalszej refleksji w postaci uporządkowania licznych pojęć oraz zarysowania działów i metod ekonomii. Trzon wystąpienia oparł na jednostkowych przykładach postaw moralnych w życiu gospodarczym, od skrajnego cynizmu i chciwości po świadectwa uczciwości i dobroci. Mocno wyeksponowany został sługa Boży Enrique Shaw z Argentyny. Podsumowanie podkreśliło znaczenie 
osobistej postawy - regulacje systemowe nie obronią bowiem przed moralnym rozkładem.

Ks. dr hab. Arkadiusz Wawer z Uniwersytetu Śląskiego wystąpił z tematem „Kościól zaangażowany w ekonomię - czy to konieczne? Ostrzegł przed dwoma pokusami Kościoła - wycofaniem się ze świata oraz zatraceniem w nim swej tożsamości. Mówca, przytaczając zarówno konserwatywne, jak i liberalne zarzuty wobec kapitalizmu, za Simone Weil skoncentrował się na problemie braku zakorzenienia człowieka. Następnie ks. Wawer powołał się na Ralfa Dahrendorfa, dla którego zarówno demokracja, jak i wolny rynek to „projekty chłodne”. Są cennymi narzędziami, ale nie budują tożsamości, sensu, zadomowienia. Tu widać wg prelegenta przestrzeń dla etyki, religii, etosu pracy, przyjaźni, dla sukcesu rozumianego szerzej niż tylko ekonomicznie, a także dyskusji nad socjalnymi zobowiązaniami państwa.

Należy zaznaczyć, że na konferencję nie dotarła poseł Maria Zuba, co uniemożliwiło zebranym wysłuchanie referatu Jak wydawać publiczne pieniądze? Ostatnią częścią wydarzenia była więc ożywiona dyskusja, zainicjowana przez ks. prof. dr. hab. Antoniego Żurka (UPJPII), która dotyczyła m.in. statusu ekonomii jako nauki, jej filozoficznych założeń oraz niezawodności przewidywań ekonomistów. Sesję zakończyło podsumowanie ks. dr. hab. Janusza Królikowskiego, prof. UP JPII, dziekana Wydziału Teologicznego Sekcja w Tarnowie, który podkreślił konieczność nieustannego dialogu między naukami teologicznymi a ekonomią oraz ogromne bogactwo inspiracji, jakie z chrześcijaństwa płyną dla życia gospodarczego. 
